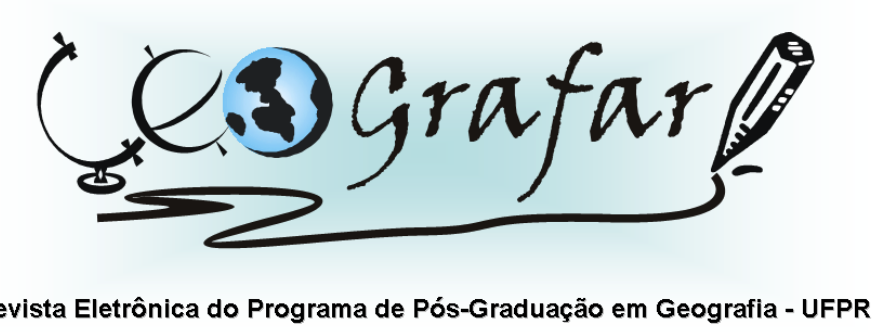

\title{
DINÂMICAS REGIONAIS NA ASSISTÊNCIA SOCIAL DO PARANÁ
}

\section{ANDRÉ ALVES TIMBÓ ${ }^{1}$}

A Assistência Social é uma política pública recente, tem como regulamentação especifica a Lei Orgânica de Assistência Social (Lei 8.742/1993). Esta Lei proporcionou novas relações para a política de assistência social ao estabelecer diretrizes como a descentralização, a participação social e as suas ações sistematizadas. Desse modo, o Sistema Descentralizado e Participativo da Assistência Social compõem-se de várias instâncias e diversas escalas. No Estado do Paraná, este sistema conta com uma instância de política e de articulação peculiar que são os Fóruns Regionais de Assistência Social (FRAS). Essa instância insere-se como escala intermediária entre o Município e o Estado, configurando-se em uma possibilidade de regionalização, portanto, um instrumento geral de análise para o geógrafo. Concomitante, há no Paraná, a regionalização administrativa da Secretaria de Estado responsável pela assistência social. Nesse contexto, a pesquisa teve como objetivo compreender a espacialidade produzida pelo processo de descentralização da Assistência Social, que oportunizou, no Paraná, a construção de novos laços regionais, conformando, assim, uma nova regionalização, bem como, a articulação entre as regionalizações da assistência social permitiu a análise dos municípios agrupados em regiões, no período de 1994 a 2005. Para alcançar os objetivos propostos, a metodologia da pesquisa consistiu na pesquisa ação, evidenciando-se a discussão da instrumentalização do conceito de região, utilizando-se de: levantamento bibliográfico, elaboração de mapas, aplicação de questionário, trabalho de campo e visitas técnicas a órgãos governamentais. Através da análise temporal das regionalizações da Assistência Social, as quais são, dos FRAS (1994) e das Secretarias de Estado da Criança e Assuntos da Família (1995) e do Trabalho, Emprego e Promoção Social (2003), obteve-se a identificação de três tendências regionais, respectivamente, classificadas em Dinâmicas Regionais Estacionária, Migratória e Desagrupadora.

Palavras-chaves: Regionalização, Paraná, Política de Assistência Social

${ }^{1}$ Mestrando em Geografia - UFPR - email: andreo_timbo@yahoo.com.br Orientadora: OLGA LÚCIA FIRKOWSKI 